\title{
Determinants of Virological Failure Among Adult Clients on First-Line Antiretroviral Therapy in Amhara Regional State, Northeast Ethiopia. A Case-Control Study
}

This article was published in the following Dove Press journal:

HIVIAIDS - Research and Palliative Care

\section{Zinabu Fentaw \\ Assresie Molla \\ Shambel Wedajo (D) \\ Wondwosen Mebratu}

School of Public Health, Wollo University College of Medicine and Health Science,

Dessie, Amhara Region, Ethiopia
Correspondence: Zinabu Fentaw

School of Public Health, Wollo University

College of Medicine and Health Science,

Dessie, Ethiopia

Tel +25I 912757286

Email zfentaw5@gmail.com
Background: Virological failure is defined as having viral load measurement greater or equal to 1000 copies $/ \mathrm{mm}^{3}$ after at least six-month exposure to antiretroviral therapy. According to the Joint United Nations Programme on HIV/AIDS (UNAIDS-2018) report, globally nearly one in five patients on first-line antiretroviral therapy had experienced virological failure. In line with this, Ethiopia federal ministry of health also reported that one in four patients had experienced virological failure in the year 2016. To date, very little is known about the predictors of virological failure in the local context. Therefore, this study intended to address the determinants of virological failure among patients on a first-line antiretroviral regimen.

Methods: A case-control study was conducted among clients on first-line antiretroviral therapy in Amhara regional state, January 2019 with a sample of 257 clients; of these, 86 clients were cases. Data were collected via patient interview and chart extraction for clinical profiles using standardized tools. Binary logistic regression was computed to identify the determinants of virological failure using Stata version 14 and the result was displayed using adjusted odds ratio with a $95 \%$ confidence interval.

Results: Out of the proposed samples, 255 clients were considered for final analysis. The odds of virological failure are higher among poor medication adherence (AOR: 10.2:95\% CI [4.1-25.8]), age<35 years (AOR: 3.07 95\% CI 1.4-6.8), low baseline CD4 (AOR 3.9: 95\% CI 1.6-9.6), and Khat chewers (AOR: 9.5:95\% CI 2.8-32.4) as compared with their counterparts.

Conclusion: Being a young age, poor immunity at the initiation of antiretroviral, Khat chewer, and poor medication adherence significantly associated with virological failure.

Keywords: HIV/AIDS, virological failure, highly active antiretroviral therapy, case-control study

\section{Introduction}

Virological failure (VF) diagnosed based on a single plasma viral load (VL) measurement of $\geq 1000$ copies $/ \mathrm{mL}$ at any time after 6 months or more on antiretroviral therapy (ART) ${ }^{1}$ which is a more proximal informative to treatment failure, is a common problem that an HIV patient faces after starting treatment. ${ }^{2}$ According to WHO and national consolidated guidelines, once the patient had commenced antiretroviral therapy, it is expected to have an undetectable viral load at sixth 
month. ${ }^{3}$ In line with this, United Nation AIDS president emergency plan for AIDS relief (PEPFAR) ambitious plan incorporates Viral suppression in three 90s strategy to end AIDs epidemics as a public health threat by 2030 through fast-tracking commitment to meet the three 90 s by $2020 ., 5$

Early Virological failure leads to a premature switch to second-line drugs, which is expensive and toxic as compared with the standard first-line regimens. ${ }^{6,7}$

However, studies show that VF is much higher than expected, and viral replication continues to be a major challenge among adult people living with HIV. In Ethiopia federal ministry of health reported that one in four patients had experienced virological failure in the year of $2016^{8}$ and also Ethiopian population-based HIV impact assessment reported in December 2018 shows only $70.1 \%$ of Urban residence adults age between 15 and 64 able to suppress their viral load numbers. ${ }^{9}$

Even though there is viral load monitoring for every client since January 2016 and July 2016 at the national level and Dessie public health institute, respectively, the zonal health department report showed that more than 190 clients face virological failure within 6 months. ${ }^{8,10}$

The predictors of this problem vary from person to person as well across settings, however very little is known about the predictors of first-line virological failure in the local setting and in many studies as well, the social and personal characteristics are not included. Hence, this study was intended to address the determinants of virological failure among patients on a first-line antiretroviral regimen.

\section{Methods}

\section{Study Design and Setting}

A case-control study conducted in Dessie City Public Facility which, is $401 \mathrm{Km}$ from Addis Ababa a capital city of Ethiopia. Antiretroviral treatment therapy started in 2003 and 2005 at the national level and in Dessie City, respectively. Whereas the national Antiretroviral Treatment Guideline was adopting for the first time in $2007^{11}$ and then updated in $2014^{12}$ and $2018 .^{2}$ According to the national health-care service delivery system, the differentiated service delivery modality allows every client to visit the health facility regularly every six, three, two, and a monthly basis based on the clients' health status and willingness. ${ }^{2}$ Every client should be monitored at 6 months soon after initiation ART and then every year for their viral load status. According to Ethiopian Public Health Institute
Dessie branch the plasma viral load level less than 150 copies $/ \mathrm{mL}$ is reported as an undetectable viral load level. There are five public facilities providing ART of which two of them are hospitals and the rest three are health centers. Overall, about 10, 378 people living with HIV/ AIDS are on antiretroviral drug treatments in Dessie City of these 9914 are adults and the rest 464 are pediatrics. ${ }^{10,13}$

\section{Study Participant and Sample Size Determination}

Adult PLHIV clients, active on first-line ART, who have a first viral load measurement between July 2018 to December 2018 with viral load result $\geq 1000$ copies $/ \mathrm{mL}$ and $<1000$ copies $/ \mathrm{mL}$ of their viral load monitoring at 6 months or more after ART initiation as a source population for cases and controls, respectively.

The sample size was calculated using Epi Info ${ }^{\mathrm{TM}} 7.2$ StatCalc by taking key predictor variables sex with odds ratio 2.5 for odds of VF in male ${ }^{13}$ with the power of $80 \%$, $95 \%$ confidence level, and two to one ratio of controls to cases.

By adding a $10 \%$ contingency, the total sample size was 257 (86 cases and 171 controls). Samples were recruited using simple random sampling techniques after randomly allocating participants using lottery methods from routine viral load register.

\section{Operational Definition}

Virological failure is diagnosed based on a single plasma viral load (VL) measurement of $\geq 1000$ copies $/ \mathrm{mL}$ at any time after 6 months or more on antiretroviral therapy. ${ }^{1}$

Treatment interruption means the patient misses his/her appointment schedule for a month or more. ${ }^{14}$

Adherence defines treatment adherence as the extent to which a person's behavior of taking medications, corresponds with agreed recommendations from a health-care provider more than $95 \%$ as good adherence and poor adherence for less than $95 \%$ of their dose of drugs. ${ }^{2}$

\section{Data Collection Tools and Procedures}

The data were collected using a structured questionnaire through an exit interview and chart extraction about the sociodemographic, baseline and recent clinical profiles and personal and social behaviors for clients, who have viral load test results between July 2018 to December 2018. The data collection tools were developed from ART national guideline, registers and ART follow-up forms. The quality 
Table I The Socio-Demographic Characteristics of Adult First-Line ART Clients in Dessie, Amhara Region Northeast Ethiopia Jan 2019

\begin{tabular}{|c|c|c|c|c|}
\hline \multicolumn{2}{|l|}{ Variables } & \multirow{2}{*}{$\begin{array}{l}\text { Frequency } \\
110(43.1 \%) \\
145(56.9 \%)\end{array}$} & \multirow{2}{*}{$\begin{array}{l}\text { Cases }(\mathbf{n}=85) \\
45(52.9 \%) \\
40(47.1 \%)\end{array}$} & \multirow{2}{*}{$\begin{array}{l}\text { Controls }(n=170) \\
65(38.2 \%) \\
105(61.8 \%)\end{array}$} \\
\hline Sex & $\begin{array}{l}\text { Male } \\
\text { Female }\end{array}$ & & & \\
\hline Residence & $\begin{array}{l}\text { Urban } \\
\text { Rural }\end{array}$ & $\begin{array}{l}214 \text { (83.9\%) } \\
4 \mid(16.9 \%)\end{array}$ & $\begin{array}{l}68(80 \%) \\
17(20 \%)\end{array}$ & $\begin{array}{l}146 \text { (85.9\%) } \\
24(14.1 \%)\end{array}$ \\
\hline Educational status & $\begin{array}{l}\text { Unable to read and write } \\
\text { Able read and write } \\
\text { Primary school } \\
\text { From } 9 \text { to } 10+3 \\
\text { First degree and above }\end{array}$ & $\begin{array}{l}73(28.6 \%) \\
20(7.8 \%) \\
81(31.8 \%) \\
65(25.5 \%) \\
16(6.3 \%)\end{array}$ & $\begin{array}{l}31(36.5 \%) \\
5(5.9 \%) \\
23(27.1 \%) \\
20(23.5 \%) \\
6(7.1 \%)\end{array}$ & $\begin{array}{l}42(24.7 \%) \\
15(8.8 \%) \\
58(34.1 \%) \\
45(26.5 \%) \\
10(5.9 \%)\end{array}$ \\
\hline Occupation & $\begin{array}{l}\text { Government employed } \\
\text { Self employed } \\
\text { Private Employed } \\
\text { Unemployed } \\
\text { Daily laborer } \\
\text { House Wife } \\
\text { Others }^{\mathrm{a}}\end{array}$ & $\begin{array}{l}32(12.5 \%) \\
92(36.1 \%) \\
24(9.4 \%) \\
12(4.7 \%) \\
54(21.2 \%) \\
36(14.1 \%) \\
5(2.0 \%)\end{array}$ & $\begin{array}{l}8(9.4 \%) \\
27(31.8 \%) \\
12(14.1 \%) \\
4(4.7 \%) \\
20(23.5 \%) \\
12(14.1 \%) \\
2(2.4 \%)\end{array}$ & $\begin{array}{l}24(14.1 \%) \\
65(38.2 \%) \\
12(7.1 \%) \\
8(4.7 \%) \\
34(20.0 \%) \\
24(14.1 \%) \\
3(1.8 \%)\end{array}$ \\
\hline Marital status & $\begin{array}{l}\text { Single } \\
\text { Married } \\
\text { Widowed } \\
\text { Divorced }\end{array}$ & $\begin{array}{l}33(12.9 \%) \\
137(53.7 \%) \\
34(13.3 \%) \\
51(20.0 \%)\end{array}$ & $\begin{array}{l}15(17.6 \%) \\
44(53 \%) \\
7(8.2 \%) \\
18(21.2 \%)\end{array}$ & $\begin{array}{l}18(10.6 \%) \\
92(54.1 \%) \\
27(15.9 \%) \\
33(19.4 \%)\end{array}$ \\
\hline
\end{tabular}

Note: ${ }^{\text {aStudents. }}$

of the data had tried to ensure through training of the data collectors, conducting pre-testing the tool and supervision during data collection.

\section{Data Management and Analysis}

The data were checked for completeness and entered into Epi-data version 3.1 then exported to Stata version 14. The data were managed by running frequencies, sorting, and listing variables and then descriptive statistics like frequencies and percentages were calculated to see the overall distribution of the study subjects with regard to the variables under the study. The binary logistic regression model was computed to identify determinants of VF by considering the HosmerLemeshow goodness-of-fit test, which was nonsignificant (0.72).

First, bi-variable analysis of binary logistic regression was conducted and those variables with a p-value of less than 0.2 were included into multi-variable analysis. In multivariable binary logistic regression variables having a p-value less than 0.05 considered as the determinant of $\mathrm{VF}$ at the level of significance of 0.05 .

\section{Ethical Consideration}

A written ethical clearance letter was obtained from the Ethical Review Committee (ERC) of Wollo University College of medicine and health sciences. The respondents were informed about the purpose of the study and written consent was obtained. The data were collected in accordance with Helsinki Declaration and the information provided by each respondent was kept strictly confidential.

\section{Result}

A total of 255 adults ART first-line users were involved in the study with a response rate of 85 (98.8\%) and 170 (99.4\%) among cases and controls, respectively.

\section{Socio-Demographic Characteristics}

The median age of the respondents was 32 and 38 years with an inter-quartile range (IQR) of 9 and 12 years for cases and controls, respectively. Female respondents contribute $40(47 \%)$ of cases and $105(61.8 \%)$ of controls (Table 1). Among urban dwellers 68 (80\%) were cases and $146(85.9 \%)$ were controls. Of the total 255 respondents, $81(31.8 \%)$ were primary school among these 23 
Table 2 The Baseline Clinical Characteristics of Adult First-Line ART Clients in Dessie, Amhara Region Northeast Ethiopia Jan 2019

\begin{tabular}{|l|l|l|l|l|}
\hline \multicolumn{2}{|l|}{ Variables } & Frequency & Cases (n=85) & Controls (n=I70) \\
\hline Baseline WHO stage & Stage I & $58(22.7 \%)$ & $14(16.5 \%)$ & $44(25.9 \%)$ \\
& Stage II & $67(26.3 \%)$ & $20(23.5 \%)$ & $47(27.6 \%)$ \\
& Stage III & $112(43.9 \%)$ & $43(50.6 \%)$ & $69(40.6 \%)$ \\
& Stage IV & $18(7.1 \%)$ & $8(9.4 \%)$ & $10(5.9 \%)$ \\
\hline \multirow{2}{*}{ Baseline Regimen } & TDF 3TC EFV & $101(39.6 \%)$ & $39(45.9 \%)$ & $62(36.5 \%)$ \\
& TDF 3TC NVP & $19(7.5 \%)$ & $8(9.4 \%)$ & $11(6.5 \%)$ \\
& AZT 3TC NVP & $48(18.8 \%)$ & $15(17.6 \%)$ & $33(19.4 \%)$ \\
& AZT 3TC EFV & $22(8.6 \%)$ & $6(7.1 \%)$ & $16(9.4 \%)$ \\
& OTHERS & $65(25.5 \%)$ & $17(20.0 \%)$ & $48(28.2 \%)$ \\
\hline
\end{tabular}

Note: ${ }^{\Delta}(d 4 T+3 T C+N V P),(d 4 T+3 T C+E F V)$.

(27.1\%) of them were cases (Table 1). Concerning respondent's occupation and marital status, 92 (36.1\%) and 136 (53.3\%) were self-employed and married, respectively (Table 1).

\section{Baseline Clinical Characteristics}

The median CD4 cell counts were 119.5 and 179 cells $/ \mu \mathrm{L}$ with an inter-quartile range of 158 and 170.5 cells $/ \mathrm{mm}^{3}$ among cases and controls, respectively. The minimum baseline CD4 cells were 4 and 9 cells $/ \mathrm{mm}^{3}$ and the maximum was 707 and 1326 cells $/ \mu \mathrm{L}$ for cases and controls, respectively. The median baseline BMI of the respondents (IQR) was $17.9(2.6) \mathrm{kg} / \mathrm{m}^{2}$ with a minimum of $14.8 \mathrm{~kg} / \mathrm{m}^{2}$ and a maximum of $34.3 \mathrm{~kg} / \mathrm{m}^{2}$ in case groups. From the baseline characteristics of the respondents, 43 (50.6\%) and $69(40.6 \%)$ were at WHO stage III among cases and controls, respectively (Table 2). From the baseline regimen $39(45.9 \%)$ cases and $62(36.5 \%)$ controls were taking TDF 3TC EFV Table 2.

\section{Recent Clinical Characteristics}

The median recent CD4 counts (IQR) were 272 (296) cells/ $\mu \mathrm{L} 1454$ (327) cells/ $\mu \mathrm{L}$ for cases and controls, respectively. The median BMI of the respondents (IQR) was $18.3(2.7) \mathrm{kg} /$ $\mathrm{m}^{2}$, among cases and also $20.25(4.8) \mathrm{kg} / \mathrm{m}^{2}$ for controls. Almost all 243 (95.3\%) of the respondents were in stage one during the clinical assessment of their viral load schedule.

Out of the total 255 respondents, $68(26.7 \%)$ were having a history of OI since ART initiation. Almost 240 (94.1\%) of the respondents were working functional status and only a few $6(2.4 \%)$ were having chronic co-morbid diseases (Table 3).

Table 3 The Recent Clinical Characteristics of Adult First-Line ART Clients in Dessie, Amhara Region Northeast Ethiopia Jan 2019

\begin{tabular}{|l|l|l|l|l|}
\hline \multicolumn{2}{|l|}{ Variables } & Frequency & Cases (85) & Controls (n=I70) \\
\hline Current Regimen & TDF 3TC EFV & $121(47.5 \%)$ & $42(49.4 \%)$ & $79(46.5 \%)$ \\
& TDF 3TC NVP & $32(12.5 \%)$ & $8(9.4 \%)$ & $24(14.1 \%)$ \\
& AZT 3TC NVP & $64(25.1 \%)$ & $24(28.2 \%)$ & $(23.5 \%)$ \\
& AZT 3TC EFV & $38(14.7 \%)$ & II (13\%) & $27(16.1 \%)$ \\
\hline Current T stage & Stage I & $243(95.3 \%)$ & $76(89.4 \%)$ & $167(98.2 \%)$ \\
& Stage II & $7(2.7 \%)$ & $4(4.7 \%)$ & $3(1.8 \%)$ \\
& Stage III & $5(2.0 \%)$ & $5(5.9 \%)$ & $0(0.0 \%)$ \\
\hline Current functional status of the patient & Working & $240(94.1 \%)$ & $77(90.6 \%)$ & $163(95.9 \%)$ \\
& Ambulatory & $15(5.9 \%)$ & $8(9.4 \%)$ & $7(4.1 \%)$ \\
\hline History of Opportunistic Infection & Yes & $68(26.7 \%)$ & $39(45.9 \%)$ & $29(17.1 \%)$ \\
& No & $187(73.3 \%)$ & $46(54.1 \%)$ & $141(82.9 \%)$ \\
\hline Non communicable disease & Yes & $6(2.4 \%)$ & $2(2.4 \%)$ & $4(2.4 \%)$ \\
& No & $249(97.6 \%)$ & $83(97.6 \%)$ & $166(97.6 \%)$ \\
\hline
\end{tabular}


Table 4 The Social and Personal Characteristics of Adult First-Line ART Clients in Dessie, Amhara Region Northeast Ethiopia Jan 2019

\begin{tabular}{|c|c|c|c|c|}
\hline \multicolumn{2}{|l|}{ Variables } & \multirow{3}{*}{$\begin{array}{l}\text { Frequency } \\
198(77.6 \%) \\
57(22.4 \%)\end{array}$} & \multirow{3}{*}{$\begin{array}{l}\text { Cases }(\mathbf{n}=85) \\
39(45.9 \%) \\
46(54.1 \%)\end{array}$} & \multirow{3}{*}{$\begin{array}{l}\text { Controls (170) } \\
159(93.5 \%) \\
11(6.5 \%)\end{array}$} \\
\hline Adherence to ARV & Good & & & \\
\hline & Poor & & & \\
\hline \multirow[t]{2}{*}{ Treatment interruption } & Yes & $37(14.5 \%)$ & $27(31.8 \%)$ & $10(5.9 \%)$ \\
\hline & No & $218(85.5 \%)$ & $58(68.2 \%)$ & $160(94.1 \%)$ \\
\hline \multirow[t]{5}{*}{ Reason for treatment interruption } & Side effect & $2(5.1 \%)$ & I (4.36\%) & I (6.25\%) \\
\hline & Illness & $9(23.1 \%)$ & $6(26.08 \%)$ & $3(18.75 \%)$ \\
\hline & Social Problem & $8(20.5 \%)$ & $6(26.08 \%)$ & $2(12.5 \%)$ \\
\hline & Hopelessness & $12(30.8 \%)$ & $6(26.08 \%)$ & $6(37.5 \%)$ \\
\hline & Use of traditional medicine & $8(20.5 \%)$ & $4(17.4 \%)$ & $4(25 \%)$ \\
\hline \multirow[t]{4}{*}{ Duration of interruption } & Less than one Month & II (29.7\%) & $5(18.5 \%)$ & $6(60.0 \%)$ \\
\hline & For one month & $10(27.0 \%)$ & $7(25.9 \%)$ & $3(30.0 \%)$ \\
\hline & For two months & $3(8.1 \%)$ & $3(11.1 \%)$ & $0(0.0 \%)$ \\
\hline & 3 months and above & $13(35.1 \%)$ & $12(44.4 \%)$ & I (I0.0\%) \\
\hline \multirow[t]{2}{*}{ Disclosing HIV status } & Yes & 199 (78.0\%) & $54(63.5 \%)$ & $145(85.3 \%)$ \\
\hline & No & $56(22.0 \%)$ & $31(36.5 \%)$ & $25(14.7 \%)$ \\
\hline
\end{tabular}

\section{Social and Personal Characteristics}

Most of the respondents 198 (77.6\%) were with good adherence among those 39 (45.9\%) were cases and 159 $(93.5 \%)$ of them were controls (Table 4). Regarding to treatment interruption $58(68.2 \%)$ of the respondents, who were never interrupted, were cases and among those, who interrupt 13 (35.1\%) were interrupted for 3 months and more. Among the respondents who were disclosed their HIV status $54(63.5 \%)$ were cases and 145 $(85.3 \%)$ of them were Controls (Table 4$)$.

\section{Behavioral Characteristics}

Most respondents 221 (86.7\%) had no multiple sexual partners and $64(75.3 \%)$ of them were cases and 124 $(48.6 \%)$ of cases use condom consistently from those 31 (36.5\%) were cases and $93(54.7 \%)$ were controls (Table 5).

Out of the total 255 respondents $231(90.6 \%), 216$ (84.7\%), $251(98.4 \%)$ of the respondents were never taken any alcohol, khat, and smoking within 1 year Prior to viral load test (Table 5).

Table 5 The Behavioral Characteristics of Adult First-Line ART Clients in Dessie, Amhara Region Northeast Ethiopia Jan 2019

\begin{tabular}{|c|c|c|c|c|}
\hline \multicolumn{2}{|l|}{ Variables } & \multirow{3}{*}{$\begin{array}{l}\text { Frequency } \\
34(13.3 \%) \\
221(86.7 \%)\end{array}$} & \multirow{3}{*}{$\begin{array}{l}\text { Cases }(\mathbf{n}=85) \\
21(24.7 \%) \\
64(75.3 \%)\end{array}$} & \multirow{3}{*}{$\begin{array}{l}\text { Controls }(n=170) \\
13(7.6 \%) \\
157(92.4 \%)\end{array}$} \\
\hline Multiple Sexual partners & Yes & & & \\
\hline & No & & & \\
\hline \multirow[t]{2}{*}{ Consistent Use of condoms } & Yes & $124(48.6 \%)$ & 31 (36.5\%) & $93(54.7 \%)$ \\
\hline & No & 98 (38.4\%) & $50(58.8 \%)$ & 48 (28.2\%) \\
\hline \multirow[t]{3}{*}{ Alcohol consumption status } & Never & $231(90.6 \%)$ & 71 (83.5\%) & $160(94.1 \%)$ \\
\hline & Sometimes & $21(8.2 \%)$ & $12(14.1 \%)$ & $9(5.3 \%)$ \\
\hline & Always & $3(1.2 \%)$ & $2(2.4 \%)$ & I (0.6\%) \\
\hline \multirow[t]{3}{*}{ Chewing Khat status } & Never & $216(84.7 \%)$ & $53(62.4 \%)$ & $163(95.9 \%)$ \\
\hline & Sometimes & $32(12.5 \%)$ & $25(29.4 \%)$ & $7(4.1 \%)$ \\
\hline & Always & 7 (2.7\%) & 7 (8.2\%) & $0(0.0 \%)$ \\
\hline \multirow[t]{3}{*}{ Smoking cigarette status } & Never & $25 I(98.4 \%)$ & $83(97.6 \%)$ & I 68 (98.8\%) \\
\hline & Sometimes & $2(0.8 \%)$ & $\mathrm{I}(\mathrm{I} .2 \%)$ & I (0.6\%) \\
\hline & Always & $2(0.8 \%)$ & I (I.2\%) & I (0.6\%) \\
\hline
\end{tabular}


Table 6 Determinants of Virological Failure Among Adult First-Line HAART Clients in Dessie, Amhara Region Northeast Ethiopia Jan $2019(\mathrm{~N}=255)$

\begin{tabular}{|c|c|c|c|c|c|}
\hline \multicolumn{2}{|l|}{ Variables } & \multirow{2}{*}{$\begin{array}{l}\text { Cases }(\mathbf{n}=85) \\
45(52.9 \%) \\
40(47.1 \%)\end{array}$} & \multirow{2}{*}{$\begin{array}{l}\text { Controls (170) } \\
65(38.2 \%) \\
105(61.8 \%)\end{array}$} & \multirow{2}{*}{$\begin{array}{l}\text { COR }(95 \% \mathrm{CI}) \\
1.82(1.07-3.08) \\
\end{array}$} & \multirow{2}{*}{$\begin{array}{l}\text { AOR }(95 \% \mathrm{Cl}) \\
\mathrm{I} .29(0.55-2.98) \\
\mathrm{I}\end{array}$} \\
\hline Sex & $\begin{array}{l}\text { Male } \\
\text { Female }\end{array}$ & & & & \\
\hline Age & $\begin{array}{l}<35 \text { years } \\
\geq 35 \text { years }\end{array}$ & $\begin{array}{l}61(71.8 \%) \\
24(28.2 \%)\end{array}$ & $\begin{array}{l}64(37.6 \%) \\
106(62.4 \%)\end{array}$ & $\begin{array}{l}4.2(2.29-7.4) \\
\text { I }\end{array}$ & $\begin{array}{l}3.07(1.4-6.8)^{*} \\
1\end{array}$ \\
\hline Baseline WHO stage & $\begin{array}{l}\text { Advanced Stage }{ }^{a} \\
\text { Early stage }^{b}\end{array}$ & $\begin{array}{l}51(60 \%) \\
34(40 \%)\end{array}$ & $\begin{array}{l}79(46.5 \%) \\
91(53.5 \%)\end{array}$ & $\begin{array}{l}1.73(1.02-2.93) \\
1\end{array}$ & $\begin{array}{l}1.73(0.76-3.93) \\
I\end{array}$ \\
\hline History of OI & $\begin{array}{l}\text { Yes } \\
\text { No }\end{array}$ & $\begin{array}{l}39(45.9 \%) \\
46(54.1 \%)\end{array}$ & $\begin{array}{l}29(17.1 \%) \\
141(82.9 \%)\end{array}$ & $\begin{array}{l}4.122(2.29-7.4) \\
I\end{array}$ & $\begin{array}{l}3.6(0.47-8.7) \\
\text { I }\end{array}$ \\
\hline Baseline CD4 & $\begin{array}{l}<200 \text { cells } / \mu \mathrm{L} \\
\geq 200 \text { cells } / \mu \mathrm{L}\end{array}$ & $\begin{array}{l}62(72.9 \%) \\
23(27.1 \%)\end{array}$ & $\begin{array}{l}99(58.2 \%) \\
71(4 I .8 \%)\end{array}$ & $\begin{array}{l}1.93(I . I-3.4 I) \\
I\end{array}$ & $\begin{array}{l}3.9(1.57-9.66) * \\
\text { I }\end{array}$ \\
\hline Recent CD4 & $\begin{array}{l}<200 \text { cells } / \mu \mathrm{L} \\
\geq 200 \text { cells } / \mu \mathrm{L}\end{array}$ & $\begin{array}{l}24(28.2 \%) \\
61(71.8 \%)\end{array}$ & $\begin{array}{l}15(8.8 \%) \\
155(91.2 \%)\end{array}$ & $\begin{array}{l}4.066(2.0-8.27) \\
1\end{array}$ & $\begin{array}{l}1.46(0.34-4.6) \\
I\end{array}$ \\
\hline Baseline BMI & $\begin{array}{l}\text { Low baseline BMI } \\
\text { Normal }^{d}\end{array}$ & $\begin{array}{l}59(69.4 \%) \\
26(30.6 \%)\end{array}$ & $\begin{array}{l}79(46.5 \%) \\
91(53.5 \%)\end{array}$ & $\begin{array}{l}2.6(I .5 I-4.54) \\
I\end{array}$ & $\begin{array}{l}1.03(0.39-2.85) \\
\mathrm{I}\end{array}$ \\
\hline Recent BMI & $\begin{array}{l}\text { Low }^{c} \\
\text { Normal }^{d}\end{array}$ & $\begin{array}{l}49(57.6 \%) \\
36(42.4 \%)\end{array}$ & $\begin{array}{l}37(21.8 \%) \\
133(78.2 \%)\end{array}$ & $\begin{array}{l}4.89(2.78-8.60) \\
I\end{array}$ & $\begin{array}{l}3.4(0.55-7.7) \\
\text { I }\end{array}$ \\
\hline Adherence Status & $\begin{array}{l}\text { Poor }^{e} \\
\text { Good }^{f}\end{array}$ & $\begin{array}{l}46(54.1 \%) \\
39(45.9 \%)\end{array}$ & $\begin{array}{l}\text { II (6.5\%) } \\
159(93.5 \%)\end{array}$ & $\begin{array}{l}17.05(8.1-35.9) \\
1\end{array}$ & $\begin{array}{l}10.23(4.1-25.8)^{*} \\
I\end{array}$ \\
\hline Treatment interruption & $\begin{array}{l}\text { Yes } \\
\text { No }\end{array}$ & $\begin{array}{l}27(31.8 \%) \\
58(68.2 \%)\end{array}$ & $\begin{array}{l}10(5.9 \%) \\
160(94.1 \%)\end{array}$ & $\begin{array}{l}7.45(3.4-16.3) \\
1\end{array}$ & $\begin{array}{l}7.05(0.26-22.2) \\
I\end{array}$ \\
\hline Care givers HIV status & $\begin{array}{l}\text { HIV negative } \\
\text { HIV positive }\end{array}$ & $\begin{array}{l}51(60 \%) \\
34(40 \%)\end{array}$ & $\begin{array}{l}73(42.9 \%) \\
97(57.1 \%)\end{array}$ & $\begin{array}{l}1.99(1.21-3.6) \\
1\end{array}$ & $\begin{array}{l}0.61(0.25-1.47) \\
\mathrm{I}\end{array}$ \\
\hline Disclosure status & $\begin{array}{l}\text { Yes } \\
\text { No }\end{array}$ & $\begin{array}{l}31 \text { (36.5\%) } \\
54(63,5 \%)\end{array}$ & $\begin{array}{l}25 \text { (14.7\%) } \\
145(85.3 \%)\end{array}$ & $\begin{array}{l}\text { I } \\
3.3(1.8-6.14)\end{array}$ & $\begin{array}{l}\text { I } \\
\text { I.82 (0.7-4.9) }\end{array}$ \\
\hline Multiple Sexual Partners & $\begin{array}{l}\text { Yes } \\
\text { No }\end{array}$ & $\begin{array}{l}21 \text { ( } 24.7 \%) \\
64(75.3 \%)\end{array}$ & $\begin{array}{l}13(7.6 \%) \\
157(92.4 \%)\end{array}$ & $\begin{array}{l}3.96(1.87-8.39) \\
1\end{array}$ & $\begin{array}{l}2.82(0.94-8.47) \\
\text { I }\end{array}$ \\
\hline Alcohol Consumption & $\begin{array}{l}\text { Yes } \\
\text { Never }\end{array}$ & $\begin{array}{l}\text { I4 (16.5\%) } \\
7 \mid(83.5 \%)\end{array}$ & $\begin{array}{l}10(5.9 \%) \\
160(94.1 \%)\end{array}$ & $\begin{array}{l}3.16(1.34-7.44) \\
1\end{array}$ & $\begin{array}{l}\text { I.6 (0.37-6.8) } \\
\mathrm{I}\end{array}$ \\
\hline Khat Chewing & $\begin{array}{l}\text { Yes } \\
\text { Never }\end{array}$ & $\begin{array}{l}32(37.6 \%) \\
53(62.4 \%)\end{array}$ & $\begin{array}{l}7(4.1 \%) \\
163(95.9 \%)\end{array}$ & $\begin{array}{l}\text { I4.I (5.9-33.7) } \\
\text { I }\end{array}$ & $\begin{array}{l}9.54(2.8-32.4)^{*} \\
\text { I }\end{array}$ \\
\hline
\end{tabular}

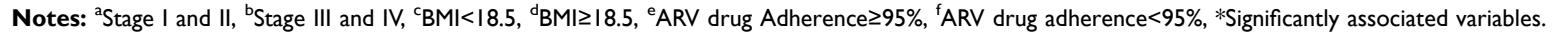

\section{Determinant Factors for VF}

During multi-variable backward logistic regression analysis age less than 35 years, low baseline CD4 counts $(<200 \mathrm{cel} 1 / \mathrm{mL})$, poor adherence and, Khat chewing practice are significantly associated with virological failure Table 6.

The likelihood of developing VF in clients with poor adherence to antiretroviral treatment is 10 times as compared with good adherence. The risk of developing virological failure among clients in a younger age group (age less than 35 years) is increased 3 times as compared with an older age group (age greater than 35 years). Those clients with baseline CD4 count less than 200 cells $/ \mu \mathrm{L}$ increase the likelihood of developing VF 4 times as compared with baseline CD4 count greater than 200cells $/ \mathrm{mm}^{3}$. Clients on first-line adult ART users, who were "Khat" chewers, are 9.5 times more likely to develop VF as compared with not Khat chewing group Table 6 . 


\section{Discussion}

In this study, the determinants of virological failure in adult antiretroviral therapy users reveal that age less than 35 years, presence Low baseline CD4 (below 200cell/mL), Khat chewing, and poor adherence to antiretroviral drugs were found to have increased odds of virological failure.

Poor adherence to ART drugs is one of the predictors of VF. The finding of this study is consistent with a study conducted in Gondar, Mekele, and Uganda, where poor adherence was the main risk factor for virological failure. Missing one or more drugs, within 7-days dose leads to high viral replication, which leads to VF. ${ }^{15-17}$ Therefore, poor adherence has a proxy indicator for Virological failure, poor immunological and Clinical outcomes, and also has its own public health implication on having a spread of HIV infection and drug resistance.

The younger age groups of antiretroviral therapy users are prone to virological failure. In line with these various studies have revealed that younger age groups were at increased risk of VF. ${ }^{15,18}$ The possible reason may be due to fear of disclosure to their family and relatives. ${ }^{19}$ So that different study shows that younger age groups are not disclosing their HIV status and disclosure is one of the predictor variable for Virological failure. ${ }^{20,21}$ Therefore, health-care providers better provide a patient-centered approach to younger age groups in order to reduce mortality in earlier ages of ART clients and increase productivity at individual and national levels.

A low baseline CD4 count is considered as the determinant of VF in this study. Different studies have shown that low baseline CD4 count was significant predictors of VF explained by the frequent occurrence of opportunistic infections that leads to disease progression subsequently increased risk of virological failure. ${ }^{22,23}$ Hence, strengthen test and Treat-all approach in clients with low baseline CD4 cell counts, commence appropriate prophylaxis, and provide intensive counseling on drug adherence.

Even though there is limited scientific paper investigating the association between "Khat" Chewing practice and Virological response on HIV/AIDS patients, in this study "Khat" is one of the predictor variables which is significantly associated to VF this may be due to the prevalence of "Khat" chewing high in the area. ${ }^{24,25}$ "Khat" chewing reduces nutritional and drug absorption, which leads to immune suppression as well "Khat" chewing leads to the use of other substances that may interact with the antiretroviral drugs, this leads to poor response to antiretroviral drug, then finally develop virological failure. ${ }^{24}$ So, Khat chewing increases the risky sexual behavior which in turn increases the spread of HIV infection from high viral load clients. ${ }^{26}$

\section{Conclusion}

Among the socio-demographic characteristics, age is negatively associated with the development of virological failure, as well in baseline clinical characteristics baseline CD4 cell count is also shows a negatively associated with the development of virological failure.

From personal and behavioral characteristics poor adherence to antiretroviral treatment and Khat chewing are the main predictor variables for virological failure. Prepare a list in the care plan for clients with poor adherence, discuss with them to resolve the root cause of adherence problem and to avoid their risky behaviors.

\section{Acknowledgment}

We would like to acknowledge Wollo University College of Medicine and Health Science Department of Public Health for its periodic follow-up and facilitation.

\section{Author Contributions}

All authors made a significant contribution to the work reported, whether that is in the conception, study design, execution, acquisition of data, analysis and interpretation, or in all these areas; took part in drafting, revising or critically reviewing the article; gave final approval of the version to be published; have agreed on the journal to which the article has been submitted; and agree to be accountable for all aspects of the work.

\section{Funding}

The source of funding is self-sponsored.

\section{Disclosure}

The authors report no conflicts of interest for this work.

\section{References}

1. UNAIDS. Global AIDS Monitoring 2018; 2018

2. EFMoH. National consolidated guidelines for comprehensive HIV prevention, care and; 2018

3. WHO. The use of antiretroviral drugs for treating and preventing HIV infection; 2016

4. Facts K. The global HIV/AIDS epidemic; 2020. (July 2018).

5. UNAIDS. An Ambitious Treatment Target to Help End the AIDS Epidemic: 2014.

6. Onoya D, Hirasen K, van den Berg L, Miot J, Long LC, Fox MP. Adverse drug reactions among patients initiating second-line antiretroviral therapy in South Africa. Drug Saf. 2018;41(12):1343-1353. doi:10.1007/s40264-018-0698-3 
7. Kimaro GD, Mfinanga S, Simms V, et al. The costs of providing antiretroviral therapy services to HIV-infected individuals presenting with advanced HIV disease at public health centres in Dar es Salaam, Tanzania: findings from a randomised trial evaluating different health care strategies. PLoS One. 2017;12:1-16.

8. Ethiopia Country/Regional Operational Plan (COP/ROP) 2017 strategic direction summary; 2017

9. EPHI, et al. Ethiopia population-based HIV impact assessment Ephia 2017-2018; December 2018:4-7.

10. Dessie City Administeration. Dessie City administration, estimated population profile, 2019 E.C.pdf; 2019 (Local Unpublished report).

11. Federal Ministry of Health. Guidelines for implementation of the antiretroviral therapy programme in Ethiopia. Fed Minist Heathl Ethiop. 2007.

12. Mamo S, et al. National comprehensive HIV prevention, care and treatment training for health care providers participant manual. ART Guidel. 2014.

13. Dessie City Zonal health Department. Dessie City Zonal Health Department Annual plan (Local Unpublished report).

14. PEPFAR. Monitoring, evaluation, and reporting indicator reference guide; September 2019.

15. Care P. Determinants of virological failure among patients on highly active antiretroviral therapy in University of Gondar Referral Hospital, Northwest Ethiopia: a case - control study. Hiv/Aids. 2017;9:153.

16. Hailu GG, Hagos DG, Hagos AK, et al. Virological and immunological failure of HAART and associated risk factors among adults and adolescents in the Tigray region of Northern Ethiopia. PLoS One. 2018;13(5):1-17. doi:10.1371/journal.pone.0196259

17. Von Braun A, Wiltshire CS, Scherrer AU, et al. Early virological failure and HIV drug resistance in Ugandan adults co - infected with tuberculosis. AIDS Res Ther. 2017;14(1):1-6. doi:10.1186/s12981016-0128-5
18. Ferrand RA, Simms V, Dauya E, et al. Articles the effect of community-based support for caregivers on the risk of virological failure in children and adolescents with HIV in Harare, Zimbabwe (ZENITH): an open-label, randomised controlled trial. Lancet Child Adolesc Health. 2017;1(3):175-183. doi:10.1016/S2352-4642(17)30051-2

19. Umar E, Levy JA, Bailey RC, et al. Virological non - suppression and its correlates among adolescents and young people living with HIV in Southern Malawi. AIDS Behav. 2018;0123456789. doi:10.1007/ s10461-018-2255-6

20. Gyamfi E, Okyere P, Enoch A, Appiah-brempong E. Prevalence of, and barriers to the disclosure of HIV status to infected children and adolescents in a district of Ghana. BMC Int Health Hum Rights. 2017;17:1-8.

21. Press D. Disclosure of HIV-positive status to sexual partner and associated factors among ART users in Mekelle Hospital. Hiv/Aids. 2015;7:209-214.

22. Abdissa A, Yilma D, Fonager J, et al. Drug resistance in HIV patients with virological failure or slow virological response to antiretroviral therapy in Ethiopia. BMC Infect Dis. 2014;14(1). doi:10.1186/1471-2334-14-181.

23. Guidelines for the prevention and treatment of opportunistic infections in HIV-infected adults; 2018

24. Soboka M, Tesfaye M, Feyissa GT, Hanlon C. Khat use in people living with HIV: a facility-based cross-sectional survey from South West Ethiopia. BMC Psychiatry. 2015;15(1):69.

25. Teklie H, Gonfa G, Getachew T, Defar A, Bekele A, Bekele A. Prevalence of Khat chewing and associated factors in Ethiopia: findings from the 2015 national Non- communicable diseases STEPS survey 2015 national Non-communicable diseases STEPS survey. Ethiop J Health Dev. 2017;31(1):320-330.

26. Abebe D, Debella A, Dejene A, et al. Original article Khat chewing habit as a possible risk behaviour for HIV infection: a case-control study. Ethiop J Health Dev. 2005;19(3):174-181.

\section{Publish your work in this journal}

HIV/AIDS - Research and Palliative Care is an international, peerreviewed open-access journal focusing on advances in research in HIV, its clinical progression and management options including antiviral treatment, palliative care and public healthcare policies to control viral spread. The manuscript management system is completely online and includes a very quick and fair peer-review system, which is all easy to use. Visit http://www.dovepress.com/testimonials.php to read real quotes from published authors. 